\title{
Effects of Livestock Grazing on Infiltration and Erosion Rates Measured on Chained and Unchained Pinyon-Juniper Sites in Southeastern Utah
}

\author{
FRANK E. BUSBY AND GERALD F. GIFFORD
}

\section{Abstract}

This study was conducted on sandy loam soils in southeastern Utah during summers of 1971 and 1972 . Forage removal and soil compaction had no consistent effect on infiltration rates. However, the clipping and compaction were an instantaneous application of forage removal and soil pressure and thus may not adequately represent long term, accumulative conditions imposed by actual grazing. Areas rested from livestock grazing since 1967 had significantly higher infiltration rates than grazed areas on unchained woodland and chained, debris-in-place sites. Grazed plots had infiltration rates comparable to rates measured on areas protected from grazing since 1969 or 1971 . Grazing did not consistently affect infiltration measured on chained, debris-windrowed sites. Infiltration rates increased on all sites as the period of rest from grazing increased. None of the 21 soil and vegetation variables included in this study were identified by multiple regression models as consistently explaining significant amounts of variation in infiltration rates. Interrill or sheet erosion rates were not significantly affected by forage removal subtreatments. No consistent relationship between erosion rates and soil compaction subtreatments or various periods of rest from grazing was found.

Domestic livestock grazing has historically been a major use of the pinyon-juniper (Pinus edulis-Juniperus osteosperma) vegetation type in Arizona, Colorado, New Mexico, Nevada, and Utah. Because the market demand for pinyon-juniper tree products is low, while that for forage products is relatively high, various vegetation modification procedures have been applied in an effort to convert these woodlands to more productive grazing land (Dortignac 1960; Arnold et al. 1964; Aro 1971).

In the most widely used plant conversion technique, large tracktype tractors drag a heavy chain through the tree stands knocking down or pulling the trees from the soil. The inherent soil disturbance covers grass seed that had previously been broadcast on the site. The resultant condition is usually referred to as "chained, debris-in-place"; hereafter referred to as DIP. Sometimes the downed trees are pushed into piles or long ridges (windrows), turning most of the treated area into cleared ground. Desired forage species are drill-planted into such sites. Areas receiving this supplementary treatment are described as "chained, debriswindrowed" or simply windrowed. Windrowing usually increases the percentage of trees killed by the chaining treatment. It also, however, results in more soil disturbance than the DIP treatments because the upper soil profile is mixed as the trees are pushed into piles by the bulldozers.

At the time of the research, authors were graduate research assistant and professor, respectively, Watershed Science Unit, College of Natural Resources, Utah State University, Logan, 94322. Dr. Busby is currently Head, Division of Range Management, College of Agriculture, University of Wyoming, Laramie.

This project was carried out in cooperation with the Bureau of Land Management (Contract 14-11-0008-2837) and the Utah Agricultural Experiment Station, Logan, 84322 .

Manuscript received December 20, 1979.
Grazing has a definite impact on the hydrologic behavior of range ecosystems. Grazing, whether by domestic or wild animals, may alter the potential infiltration and erosion rates of an area by reducing the protection afforded by vegetation, by reducing or scattering litter, and by compacting the soil. In their summary of the literature on the relation of livestock grazing intensity to infiltration, Gifford and Hawkins (1978) noted that heavy grazing by livestock reduced infiltration rates to about one-half of rates measured for ungrazed conditions and lightly or moderately grazed conditions reduced infiltration rates to about $3 / 4$ of the ungrazed condition. The conclusion that livestock grazing reduces infiltration and sometimes increases erosion seems to be valid. But such results seem to have been significant only when grazing intensity has been great enough to: (1) reduce the total plant cover below some critical level, (2) prevent the plant community from producing and maintaining mulch or litter cover, and/or (3) significantly alter the structural characteristics of the soil-particularly those related to soil porosity. On arid and semiarid $(300 \mathrm{~mm}$ annual precipitation) rangeland, all of the above factors are important in controlling infiltration and erosion. However, no single factor or group of factors has been identified that consistently influences infiltration and erosion under all circumstances. Thus no models have been developed that can help the range manager predict the impact of various management activities.

Objectives of this study were to determine (on sandy loam soils) the effects of grazing and varying periods of rest from grazing on infiltration and erosion (interrill crosion) rates of unchained woodland, DIP, and windrowed pinyon-juniper sites. These measurements were then to be used in developing guidelines for grazing management of pinyon-juniper rangeland that would protect and improve the hydrologic condition of the watershed. Of particular interest were the following items:

1. Influence of grazing on infiltration and interrill or sheet erosion rates, especially as related to surface soil changes and vegetation modification.

2. Separation of the grazing impact into forage removal and trampling effects.

3. Changes in infiltration and interrill erosion rates as a function of time following exclusion of grazing from an area, and 4. Development of multiple regression models for predicting infiltration and interrill erosion rates of unchained, DIP, and windrowed pinyon-juniper rangeland subject to various grazing situations.

\section{Methods and Study Area}

The study site is located within the Maverik Point/Cyclone Flat/Shiek's Flat area on Utah Highway 261, between Natural Bridges National Monument and Mexican Hat, Utah, and approximately $70 \mathrm{~km}$ west of Blanding, Utah. Elevation of the study area is approximately $2,150 \mathrm{~m}$ and it lies within the confines of the 
Colorado Plateau. Annual precipitation ranges from 130 to 560 $\mathrm{mm}$ per year.

Soils on the study areas are wind derived from a sandstone parent material (Aridic Argiustolls-Typic Arguistolls association), and may extent to a depth of approximately $1.5 \mathrm{~m}$. The $\mathrm{pH}$ of the soil is slightly basic, averaging about 8.0. Organic matter content is low, slightly less than $2.0 \%$. Soil texture is a sandy loam with few rocks present.

The various rangeland treatments considered in this discussion are as follows:

(1) Pinyon-juniper (Pinus spp. and Juniperus spp.) woodland chained, debris windrowed; seeded to crested wheatgrass (Agropyron cristatum): Treatment conditions included currently grazed, grazing excluded since 1967, and grazing excluded since 1971 (Table 1).

(2) Pinyon-juniper woodland chained, debris left in place; seeded to crested wheatgrass. Treatment conditions included currently grazed, grazing excluded since 1967, grazing excluded since 1969, and grazing exluded since 1971 (see Table 1).

(3) Natural pinyon-juniper woodlands. Treatment conditions included currently grazed, grazing excluded since 1967, grazing excluded since 1969, and grazing excluded since 1971 (see Table 1).

Selected hydrologic, vegetal, and edaphic parameters were measured during June-July immediately following the spring grazing period and after 2 months of rest from grazing (approximately August 20) during the summers of 1971 and 1972.

Infiltration rates were determined with a Rocky Mountain infiltrometer (Dortignac 1951). The infilt rometer utilizes small, movable $0.23 \mathrm{~m}^{2}$ plots. Rainfall application rates ranged from 7.5 to 12.5 $\mathrm{cm} / \mathrm{hr}$. All plots were prewet and soils allowed to drain to field capacity prior to each infiltrometer run. Infiltration rates (rainfall application rate minus runoff rate) were determined from the 0 to 3 minute period and thereafter at 5 minute intervals to 28 minutes. Sediment production was determined by thoroughly mixing all runoff collected during the 0 to 8 minute, 8 to 18 minute, and 18 to 28 minute time periods and then taking a 1-pint integrated sample from each time period. The sediment was oven dried and sample weights were expressed in $\mathrm{kg} / \mathrm{ha}$. All treatments were replicated 12 to 15 times, for a total number of 948 plots over the two-year period.

\section{Clipping Subtreatments}

Following installation of infiltrometer plots, one-third of the plots inside grazing exclosures were clipped at $7.5 \mathrm{~cm}$ stubble height to simulate forage removal occurring on adjacent grazed areas (hereafter referred to as " $50 \%$ clipped"). Another one-third of the plot had all above-ground plant material removed by clipping at ground level and picking litter from the soil surface (" $100 \%$ clipped"). These plots provided information on hydrologic effects associated with forage removal but without soil disturbance associated with livestock grazing. The remaining ungrazed plots and

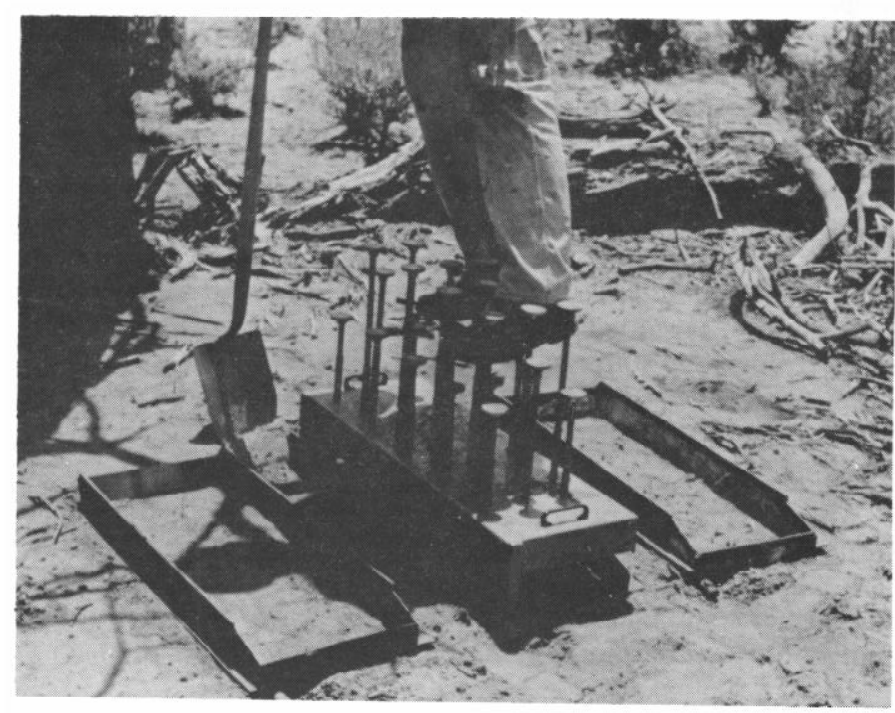

Fig. 1. Trampling device used to apply compaction subtreatments.

those on grazed areas received no clipping subtreatment (" $0 \%$ clipped").

\section{Soil Compaction Subtreatments}

Lull (1959) reported that cattle exert static or standing loads (averaged over entire surface area of hooves) of $10.9 \mathrm{~kg} \mathrm{~cm}^{-2}$ (24 lbs in $^{-2}$ ); however, two or four times this static load can occur when the animal moves. To determine the hydrologic effect of soil compaction (with no associated forage removal), randomly selected plots in ungrazed exclosures had 0,30 , or $60 \%$ of their surface area compacted with a force of $13.6 \mathrm{~kg} \mathrm{~cm}^{-2}\left(30 \mathrm{lb} \mathrm{in}^{-2}\right)$. This force was chosen as a compromise between static and moving loads, but favoring standing conditions. All plots were dry when soil compaction subtreatments were applied.

To insure uniform soil compaction subtreatments between plots, a compaction frame (Fig. 1) was designed to fit the infiltrometer plot and the same trampling "feet" were used to compact each plot (one-half used for the $30 \%$ compaction and all used for the $60 \%$ ). Care was taken in installing and removing the frame to prevent the "feet" from causing any disturbance other that compaction.

\section{Vegetative Cover}

Prior to sprinkling, but following the clipping or compaction subtreatments, vegetative cover and soil surface characteristics of each infiltrometer plot were determined with an ocular point quadrat frame (Ibrahim 1971). Intercepts of vegetation, litter, rock, or bare soil were recorded for 100 points covering the entire plot.

Table 1. Descriptions of chained study sites near Blanding, Utah.

\begin{tabular}{|c|c|c|c|c|}
\hline Chaining project title & Treatment method & Date-of treatment & Species seeded & Grazing history \\
\hline Maverick Point & $\begin{array}{l}\text { a. Chained debris in } \\
\text { place }\end{array}$ & Fall, 1961 & Crested wheatgrass & $\begin{array}{l}\text { Grazed from May } 1 \text { to June } 15 \text { and October } 1 \text { to } \\
\text { November } 1 \text { each year with cattle. Intensity ob- } \\
\text { served to be moderate to heavy. This grazing man- } \\
\text { agement has been used for several years. Grazing } \\
\text { exclosures established in } 1969 \text { and } 1971 \text {. }\end{array}$ \\
\hline
\end{tabular}

b. Chained windrowed Fall, 1964

Cyclone Flat

Chained debris-in- Fall, 1961 place

U.S.U. Research Plots a. Chained debris-in- Fall, 1967 place

b. Chained windrowed Fall, 1967
Crested wheatgrass and fourwing saltbush

Grazed as above. Grazing exclosures established Crested wheatgrass in 1971.

Grazed as above. Grazing exclosures established in 1969 and 1971.

Crested wheatgrass

Grazing excluded fall, 1967. Grazed as above prior to 1967.

Crested wheatgrass

Grazing excluded fall, 1967. Grazed as above prior to 1967. 


\section{Slope}

Percent slope was calculated by measuring the drop in elevation from the back to the front of the plot frame. Slopes involved in this study ranged from 1 to $10 \%$ and averaged $6 \%$.

\section{Soil Samples}

Immediately following an infiltration erosion test, two $7.5 \mathrm{~cm}$ diameter aluminum cylinders were pressed into the soil within the plot frame boundaries allowing extraction of 2.5 and $7.5 \mathrm{~cm}$ deep soil core samples. These two soil samples were used to determine bulk density, saturated hydraulic conductivity, porosity, texture, and percent water stable aggregates existing at the two depths. Soil cores were collected approximately 24 hours after the cylinders were pressed into the soil.

\section{Plant Biomass}

Above-ground plant biomass present within each plot during the infiltration test was clipped at ground level after foliage had dried. The material was oven dried and weights converted to $\mathrm{kg} \bullet \mathrm{ha}^{-1}$ of herbage or standing crop. This measure was used as an additional indication of vegetation's affect on infiltration and erosion.

\section{Air Permeameter}

$\Lambda \mathrm{fter}$ the soil profile had drained to field capacity following the infiltration-erosion test (approximately 2 hours), an air permeameter (Gifford et al. 1977) was used to determine the resistance of the moist soil to airflow. The air permeameter consists of an air cylinder, regulator, air valve, pressure gauge, air hose, and metal cup. The cup has an inside diameter of $4.3 \mathrm{~cm}$ and penetrates the soil until a flange around the cup is in contact with the soil surface. Air is released from the tank by the valve and flows through the soil cup into the soil. The resistance of the soil to the air causes a buildup of pressure which is reported on the pressure gauge.

\section{Lab Procedures}

Saturated hydraulic conductivity, capillary and total porosity, and bulk density were determined for the 2.5 and $7.5 \mathrm{~cm}$ deep soil cores following each field sampling period. Texture and percent water stable aggregates were determined for the AugustSeptember, 1971, sampling period.

\section{Saturated Hydraulic Conductivity}

Water flow through relatively undisturbed, previously saturated soil cores was measured by maintaining $1 \mathrm{~cm}$ head above the core, allowing a constant percolation rate $\left(\mathrm{ml} \mathrm{min}^{-1}\right)$ to be reached during a preliminary 30 -minute period, and recording the water flow through the soil core during the next 10 minutes. Water temperature and exact depth of soil in each core was measured and used in the following formula to convert measured percolation rates to comparable values (Hoover, Olson, and Metz 1954):

$$
S H C=(P / t)(h / H)\left(V_{\mathrm{T}} / V_{\mathrm{s}}\right)
$$

where:

$S H C=$ saturated hydraulic conductivity $\left(\mathrm{ml} \mathrm{min}^{-1}\right)$

$P=$ volume of water $(\mathrm{ml})$ transmittcd through soil core

$t=$ time of test in minutes

$h=$ height of soil core in $\mathrm{cm}$

$H=$ total height of water column (height of core plus head of water in $\mathrm{cm}$

$V_{\mathrm{T}}=$ viscosity of water at temperature " $\mathrm{T}$ "

$V_{\mathrm{s}}=$ viscosity of water at standard temperature $\left(15.5^{\circ} \mathrm{C}\right)$

Saturated weight of the soil was determined immediately after conclusion of the saturated hydraulic conductivity test.

\section{Porosity and Bulk Density}

Moisture was drained from the soil cores under $30 \mathrm{~cm}$ tension (1/32 atmosphere) using a blotter-tension table (Hoover et al. 1954). Tension was applied for $24 \mathrm{hrs}$ and then core weights determined. Soil cores were oven dried at $105^{\circ} \mathrm{C}$ for $24 \mathrm{hrs}$ and reweighed. Saturated weight, weight after draining at $30 \mathrm{~cm}$ tension, oven dry weight, and soil core volume was used in the following formulas to compute capillary porosity (CP), total porosity (TP), and bulk density (BD):

$$
\begin{aligned}
C P & =\frac{S-T}{V} \\
T P & =\frac{S-D}{V} \\
B D & =\frac{D}{V}
\end{aligned}
$$

where

$S=$ weight of saturated soil

$T=$ weight of soil dried at $30 \mathrm{~cm}$ tension for 24 hours

$D=$ weight of soil oven dried at $105^{\circ} \mathrm{C}$ for 24 hours

$V=$ volumne of soil mass

\section{Texture and Water Stable Aggregates}

Soil texture was determined with the hydrometer method of Bouyoucos (1962). Percentage of water stable aggregates was measured by omitting the Calgon in the hydrometer method.

\section{Analysis of Data}

Differences in infiltration and sheet erosion rates between treatments were analyzed using analysis of variance techniques. Three series of analyses were conducted for each sampling period: (1) clipping and compaction sub-treatment within each vegetationgrazing condition combination wcre analyzed to determine the effect of instantaneous forage removal or soil compaction on infiltration or erosion, (2) data gathered from areas with similar grazing histories within unchained, DIP, and windrowed sites were analyzed to determine the impact of livestock grazing or infiltration and sheet erosion, and (3) grazing conditions among vegetative conditions were analyzed to determine the impact of chaining treatments on sites with similar grazing history.

When analysis of variance indicated that significant differences $(P \leq 0.10)$ existed between clipping subtreatments, compaction subtreatments, or grazing conditions, Duncan's new multiple range test was used to evaluate treatment means (Duncan 1955).

Stepwise multiple regression analyses were used to determine the relationship between soil and vegetation factors and infiltration and sheet erosion rates. Variables explaining significant $(P \leq .10)$ amounts of variation in infiltration and erosion rates were identified by regression analysis techniques. The relationship between significant variables and infiltration and sheet erosion rates were further interpreted by evaluation of correlation coefficients.

\section{Infiltration Studies}

\section{Results and Discussion}

\section{Unchained Woodland}

The only consistent and significant difference was a higher infiltration capacity measured on plots protected from grazing since

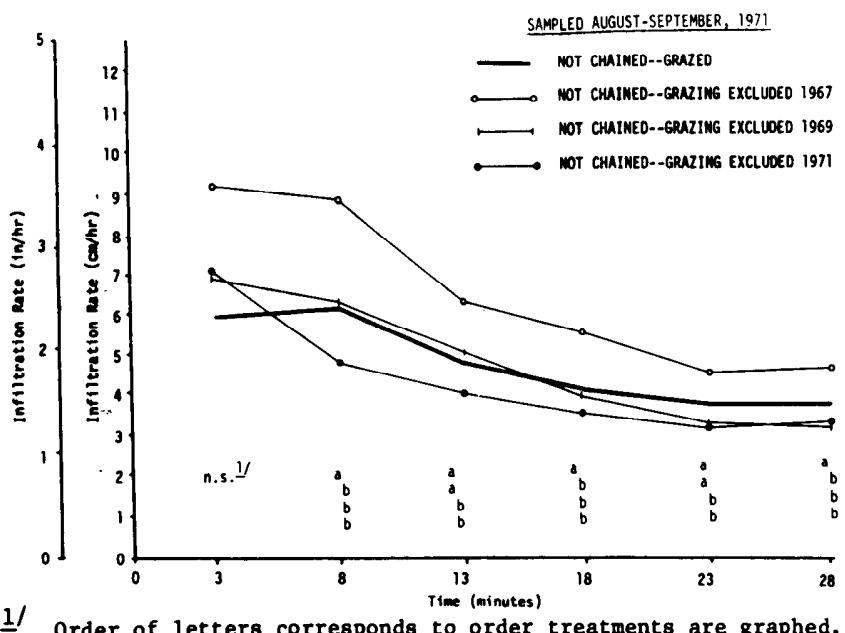
Treatments matched with the same letter are not statistically different $(\mathrm{P} \leq 0.10)$.

Fig. 2. Infiltration rates measured on unchained woodland sites sampled August-September, 1971. 
1967 (Fig. 2). Infiltration rates of plots protected since 1969 or 1971 did not differ from those of plots grazed from May 1 to June 15 during 1971 and 1972.

Infiltration rates were not altered by soil compaction subtreatments applied to the unchained woodland sites.

\section{Chained, debris-in-place sites}

Plots protected from grazing since 1967 and 1969 had consistently and generally significantly higher infiltration rates than plots protected from grazing in 1971 or plots grazed during the study (Fig. 3).

Clipping and soil compaction subtreatments did not affect infiltration rates on debris in place plots.

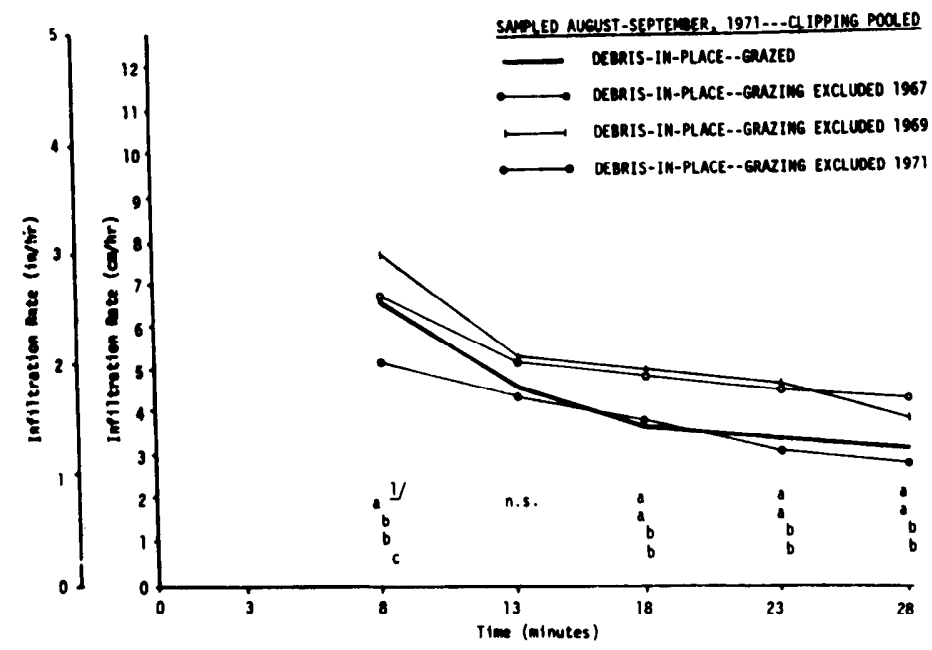

Fig. 3. Infiltration rates measured on debris in place sites sampled AugustSeptember, 1971. No compaction treatments; data pooled over $0 \%, 50 \%$, and $100 \%$ clipping treatments.

\section{Chained, Windrowed Sites}

Neither grazing nor protection from grazing consistently influenced the rate of infiltration on windrowed sites.

Clipping and soil compaction subtreatments did not affect infiltration rates on windrowed plots.

\section{Discussion of Infiltration Results \\ Influence of Clipping Subtreatments}

Because forage removal by clipping had an instantaneous effect (rather than an accumulated effect as occurs with long-term, continuous grazing), the clipping subtreatments did not simulate actual livestock grazing other than by simply removing protective vegetative material. Their primary purpose was, therefore, to provide three conditions of vegetal cover on the plots during the infiltration-erosion test.

The clipping subtreatments had no consistent or statistically measurable affect on infiltration rates on DIP or windrowed sites. This is surprising because most literature concludes that vegetal cover exerts a major influence on infiltration (summrized by Meeuwig and Packer 1976). The reasoning is that cover reduces the amount of surface sealing by fine soil particles; and increases hydraulic roughness, allowing water to be held on the soil surface until infiltration can take place (Pearse and Woolley 1936; Rauzi and Kuhlman 1961; Rauzi et al. 1968; Meeuwig 1970). Extensive literature reviews by Wolff (1970) and Branson et al. (1972) all support this conclusion. However, careful evaluation of the basic literatue reveals that most of these studies were concluded in relatively humid areas that have a cover potential of 50 to $100 \%$. The influence of vegetal cover on infiltration was much less consistent when plant cover dropped below $50 \%$.

Rauzi and Smith (1973) studied the relationship between grazing intensity and infiltration rates on threc soils at the Central Plains Experimental Range in eastern Colorado. The Ascalon Sandy Loam and the Nunn Loam had significantly lower infiltration rates for heavily grazed areas than for lightly or moderately grazed sites. There was also a strong positive correlation between vegetal cover and infiltration rates on these two soils. However, no difference in infiltration rates was found between grazing treatments on Shingle Sandy Loam. On this site the light, moderate, and heavy grazing treatments all had less than $40 \%$ total cover. The authors concluded that infiltration rates on Shingle Sandy Loam did not respond to grazing treatments because equal splash erosion and soil sealing occurred on all three grazing treatments.

It would appear that when vegetal cover is less than 40 or $50 \%$. the positive influence of cover is interacting with many other site specific factors. Kincaid et al. (1964), working on semiarid range in Arizona, found a high correlation between the amount of gravel in the surface one-fourth inch of soil and the infiltration rate. This correlation only held for sites with less than $40 \%$ vegetative cover. As the vegetative cover increased, the influence of gravel decreased until it was entirely overshadowed by that of vegetal cover.

Thompson (1968) also reported that vegetation was not a controlling factor in the relationship between grazing and infiltration of Badger Wash in western Colorado, where percent cover is less than $35 \%$. He indicated a higher correlation between infiltration rates and the sampling season than between infiltration and any vegetal or soil factors studied.

Grazing has reduced infiltration rates on many areas. This reduction is usually partially at tributed to forage being removed by livestock, but studies by Rauzi and Smika (1963) indicate that forage removal produces an accumulative effect rather than an instantaneous effect. Their study compared areas grazed throughout the season, clipped only in the fall with none of the grazed material left as litter, and clipped in the fall with one-half of the material returned to the plot as litter. Both of the plots clipped in the fall had significantly higher infiltration rates than the plots clipped throughout the season. No differences attributable to litter being returned to the plots were found between the two fall clipped plots. A season of clipping reduced infiltration while instantaneous forage removal immediately prior to infiltration tests had no effect.

Instantaneous removal of vegetation does not seem to alter infiltration. Otherwise, a decrease in infiltration rate would have occurred on plots where all vegetal cover was removed $(100 \%$ clipped). This latter conclusion may be partially explained by the growth characteristics of crested wheatgrass. This plant grows as a bunchgrass and there is not much difference between basal cover and foliage cover. The "100\% clipped" subtreatment removed all the foliage cover, but did not affect the proportion of the soil protected by the basal cover.

\section{Influence of Soil Compaction Subtreatments}

The soil compaction subtreatments $(0,30$, and $60 \%$ of the dry soil surface compacted at $13.6 \mathrm{~kg} \cdot \mathrm{cm}^{-2}$ prior to infiltration test) had no consistent or statistically measureable effect on infiltration rates recorded on unchained woodland, DIP, or windrowed sites. Soil compaction (or related measurements such as bulk density or porosity) has been reported as a factor influencing infiltration, but most studies indicated that soil compaction is primarily a problem on fine textured soils (Lull 1959; Reynolds and Packer 1962). Apparently, the sandy loam soil occurring on the southeastern Utah study site did not contain enough clay and silt particles to be affected by the compaction subtreatments. It must be noted, however, that these subtreatments were an instantaneous, short-term (less than 1 minute) application of pressure. Also, the compaction subtreatments represented the static pressure exerted by a mature cow. Considerably more pressure occurs when the animals walk. A long-term history of compaction, as might result from a season or repeated seasons of grazing, could have a different effect.

\section{Influence of Grazing and Varying Periods of Rest from Grazing}

Rest from livestock grazing since 1967 significantly increased infiltration rates on unchained woodland and on chained debris in place plots, but not on windrowed plots. Unchained woodland plots grazed during 1971 and 1972 from May 1 to June 15 had rates 
Table 2. Infiltration rates measured on unchained woodland, debris in place sites, and windrowed sites during four sampling periods.

\begin{tabular}{|c|c|c|c|c|c|c|c|}
\hline \multirow[b]{2}{*}{ Sampling period } & \multirow[b]{2}{*}{ Vegetative condition } & \multicolumn{4}{|c|}{ Protected from grazing since 1967 Protected from grazing since 1971} & \multicolumn{2}{|c|}{ Grazed } \\
\hline & & $\begin{array}{l}13-18 \text { minute } \\
\text { time interval } \\
\left(\mathrm{cm} \mathrm{hr}{ }^{1}\right)\end{array}$ & $\begin{array}{l}23-28 \text { minute } \\
\text { time interval } \\
\left(\mathrm{cm} \mathrm{hr}{ }^{1}\right)\end{array}$ & $\begin{array}{l}13-18 \text { minute } \\
\text { time interval } \\
\left(\mathrm{cm} \mathrm{hr} r^{-1}\right)\end{array}$ & $\begin{array}{l}23-28 \text { minute } \\
\text { time interval } \\
\left(\mathrm{cm} \mathrm{hr}^{-1}\right)\end{array}$ & $\begin{array}{l}13-18 \text { minute } \\
\text { time interval } \\
\left(\mathrm{cm} \mathrm{hr}^{-1}\right)\end{array}$ & $\begin{array}{l}23-28 \text { minute } \\
\text { time interval } \\
\left(\mathrm{cm} \mathrm{hr} \mathrm{hr}^{-1}\right)\end{array}$ \\
\hline \multirow{3}{*}{ June-July, 1971} & Unchained woodland & $6.1 \mathrm{a}^{1}$ & $4.6 \mathrm{~b}$ & $4.8 \mathrm{a}$ & $4.2 \mathrm{a}$ & $4.7 \mathrm{~b}$ & $3.7 \mathrm{a}$ \\
\hline & Debris in place & $6.7 \mathrm{a}$ & $5.6 \mathrm{a}$ & $5.6 \mathrm{a}$ & $3.8 \mathrm{a}$ & $6.1 \mathrm{a}$ & $4.3 \mathrm{a}$ \\
\hline & Windrowed & $5.6 \mathrm{a}$ & $4.6 \mathrm{~b}$ & $3.5 \mathrm{~b}$ & $3.1 \mathrm{~b}$ & $4.7 \mathrm{~b}$ & $3.5 \mathrm{a}$ \\
\hline \multicolumn{8}{|c|}{ August- } \\
\hline \multirow{3}{*}{ September, 1971} & Unchained woodland & $3.1 \mathrm{a}$ & $3.4 \mathrm{a}$ & $5.7 \mathrm{a}$ & $4.7 \mathrm{a}$ & $4.2 \mathrm{a}$ & $4.0 \mathrm{a}$ \\
\hline & Debris in place & $3.9 \mathrm{a}$ & $2.8 \mathrm{a}$ & $5.0 \mathrm{ab}$ & $4.4 \mathrm{ab}$ & $3.7 \mathrm{a}$ & $3.3 \mathrm{ab}$ \\
\hline & Windrowed & $3.9 \mathrm{a}$ & $3.3 \mathrm{a}$ & $4.2 \mathrm{~b}$ & $3.6 \mathrm{~b}$ & $3.9 \mathrm{a}$ & $3.0 \mathrm{~b}$ \\
\hline \multirow{3}{*}{ June-July, 1972} & Unchained woodland & $7.0 \mathrm{a}$ & $5.7 \mathrm{a}$ & $5.6 \mathrm{a}$ & $4.4 \mathrm{a}$ & $5.1 \mathrm{a}$ & $4.2 \mathrm{a}$ \\
\hline & Debris in place & $6.0 \mathrm{ab}$ & $5.0 \mathrm{a}$ & $4.6 \mathrm{~b}$ & $4.4 \mathrm{a}$ & $4.9 \mathrm{a}$ & $3.8 \mathrm{a}$ \\
\hline & Windrowed & $5.0 \mathrm{~b}$ & $4.7 \mathrm{a}$ & $4.6 \mathrm{~b}$ & $4.8 \mathrm{a}$ & $4.2 \mathrm{a}$ & $4.2 \mathrm{a}$ \\
\hline \multirow{4}{*}{$\begin{array}{l}\text { August-- } \\
\text { September, } 1972\end{array}$} & & & & & & & \\
\hline & Unchained woodland & $6.6 \mathrm{a}$ & $5.4 \mathrm{a}$ & $5.3 \mathrm{a}$ & $4.5 \mathrm{a}$ & $5.1 \mathrm{a}$ & $4.6 \mathrm{a}$ \\
\hline & Debris in place & $6.3 \mathrm{ab}$ & $5.3 \mathrm{a}$ & $4.3 \mathrm{a}$ & $3.7 \mathrm{a}$ & $5.3 \mathrm{a}$ & $4.8 \mathrm{a}$ \\
\hline & Windrowed & $5.2 \mathrm{~b}$ & $4.3 \mathrm{~b}$ & $4.0 \mathrm{a}$ & $3.8 \mathrm{a}$ & $3.8 \mathrm{~b}$ & $3.8 \mathrm{a}$ \\
\hline
\end{tabular}

'Means within sampling periods followed by the same letter are not statistically significant $(P \leq 0.10)$.

comparable to those of plots protected from grazing since 1969 or 1971 .

It seems that an unchained woodland area with no prior history of site disturbances is impacted by grazing more severely than DIP areas with a history of some disturbance (two-way chaining and aerial seeding) and windrowed areas with a history of considerable disturbance (one-way chaining, debris disposal, drill seeding). Conversely, it might be concluded that maximum disturbance of the factors influencing infiltration occurred on the windrowed sites during the vegetation conversion treatments. Therefore livestock grazing did not further reduce infiltration on the windrowed site. In addition, rest from grazing since 1967 was not enough to allow windrowed sites to completely recover from the disturbance associated with vegetation conversion (Table 2).

Debris in place sites had been sufficiently disturbed by the chaining treatments so that livestock grazing did not consistently further reduce infiltration rates. However, the disturbance associated with chaining was not permanent, and some recovery of infiltration capacity was made on DIP sites protected since 1967 and 1969.

Infiltration rates on woodland sites were consistently reduced by livestock grazing. Disturbance by livestock was not permanent and infiltration capacity recovered on plots protected from grazing since 1967

\section{Factors Influencing Infiltration Rates}

Twenty-one different variables were identified by multiple regression models as explaining significant amounts of variation in infiltration rates measured on unchained woodland, debris in place sites, and windrowed sites during one or more sampling periods. However, none of these variables proved consistently useful for explaining variation in infiltration during all vegetationconversion/grazing-condition combinations studied (Table 3). This result undoubtedly reflects the complex nature of the infiltration process (Gifford 1979) and explains the frustration of other researchers who have tried to develop statistical models to predict infiltration rates on rangelands successfully. Results here should provide encouragement for compiling infiltration data in the form of $A$ and $S$ coefficients for use with the Philip equation (Jaynes and Gifford 1980) rather than using soil and vegetation parameters that are not only time consuming to measure but are often not applicable to the problem at hand. In fact, simple soil and vegetation measures may be better related to the coefficients in Philip's equation than to infiltration rates themselves (Gifford 1978).

Table 3. Variables explaining significant $(P \leq 0.10)$ amounts of variation in infiltration rates measured on unchained woodland, debris in place, and windrowed sites-grazing conditions separated-during the 23-28 minute time interval (June-July, 1971 sampling period). Variables are listed in order of importance as identified by the stepwise multiple regression analyses.

\begin{tabular}{llllll}
\hline \hline Vegetative condition & Grazing excluded 1967 & Grazing excluded 1969 & Grazing excludcd 1971 & Grazcd during study \\
\hline Unchained woodland & None & $2.5 \mathrm{~cm}$ bulk density & None & $\begin{array}{l}2.5 \mathrm{~cm} \text { saturated hydraulic } \\
\text { conductivity }\end{array}$
\end{tabular}

Accumulated $R^{2}$

Debris in place

None

$2.5 \mathrm{~cm}$ total porosity
$7.5 \mathrm{~cm}$ saturated hydraulic $2.5 \mathrm{~cm}$ capillary porosity conductivity

Forage on plot at end of infiltration test

$2.5 \mathrm{~cm}$ bulk density

$80 \%$

None

Accumulated $R^{2}$

Windrowed

Accumulated $R^{2}$
$16 \%$

Forage on plot at end of $2.5 \mathrm{~cm}$ bulk density infiltration test

$19 \%$

Forage on plot at end of infiltration test

Pcrcent cover-bare ground infiltration test

$7.5 \mathrm{~cm}$ capillary porosity

$7.5 \mathrm{~cm}$ total porosity

$2.5 \mathrm{~cm}$ total porosity

$61 \%$

$56 \%$

Not applicable None

$2.5 \mathrm{~cm}$ capillary porosity

$31 \%$ 


\section{Erosion Studies}

Unchained Woodland

No consistent relationships were measured between grazing conditions or compaction subtreatments and sheet erosion rates on woodland sites.

\section{Chained, Debris in Place Sites}

No consistently significant differences in sheet erosion rates attributable to clipping or soil compaction subtreatments or grazing conditions were measured.

\section{Chained, Windrowed Sites}

No consistent trends in erosion rates attributable to clipping subtreatments, soil compaction subtreatments, or grazing condition were identified on windrowed areas.

\section{Discussion of Erosion Results}

Few instances of erosion rates being significantly affected by clipping subtreatments were recorded. Meeuwig (1970), Marston (1952), and Packer (1951) have reported that $65-70 \%$ cover is needed to control erosion on range capable of producing a nearly continuous plant cover. This recommendation is obviously not very useful for arid and semiarid ranges $(<300 \mathrm{~mm}$ annual precipitation).

Literature indicates that $0 \%$ compacted plots should have resulted in low erosion rates, with higher erosion rates being associated with plots receiving the $60 \%$ compacted subtreatment (Meeuwig and Packer 1976). However, this generality did not hold true in this case.

Statistical analyses rarely indicated that grazing increased erosion.

\section{Factors Influencing Erosion Rates}

Attempts at relating soil and vegetation variables to measured sheet erosion were generally not successful. An orthogonal comparison representing grazing condition and percent total cover indicated that these two variables consistently explained significant amounts of variation in measured sheet erosion rates.

In general, grazing and the associated effects on vegetation had a greater influence on sheet érosion than on infiltration. Splash erosion and soil sealing probably occurred at an equal rate on all study sites. This is indicated by the infiltration data. However, the additional amount of vegetation (both alive and dead plant material) on plots protected from grazing and on plots receiving the 0 and $50 \%$ clipped subtreatments obstructs overland flow and allows sediment to settle to the soil surface.

\section{Conclusions}

Results of this study combined with data in relevant literature provide the following management guidelines for maintaining or improving watershed conditions on pinyon-juniper rangelands similar to those evaluated in this study.

1. Areas with sandy loam soils having less than 5 to $10 \%$ slope can be converted from woodland to grassland by chaining and seeding without appreciable change in watershed characteristics if debris are left scattered on the soil surface rather than pushed into piles or windrows.

2. Spring-fall grazing (when comparcd to areas protected from grazing for 4-5 years) significantly reduced infiltration rates on unchained woodland and debris in place sites, but generally did not alter infiltration rates on windrowed sites. Similar results a re lacking for erosion rates. These results are interpreted to mean that site disturbance (by chaining, debris disposal, and drill seeding) was so great on windrowed sites that grazing caused no additional hydrologic impact on windrowed sites. Because of this initial site disturbance, and considering the hydrologic value of debris being scattered over the soil surface, wind rowing is not recommended as a management technique unless site analysis indicates it is appropriate for specific management objectives.

3. No specific grazing management recommendations are suggestcd by the results of this study. Long-term spring-fall livestock grazing that removed $45-70 \%$ of the current year's forage production did significantly reduce infiltration, though shcct crosion rates were not affected. Based on data from protected exclosures, recovery of infiltration rates on grazed sites occurs for at least 4-5 years.

\section{Literature Cited}

Arnold, J.F., D.A. Jameson, and E.H. Reid. 1964. The pinyon-juniper type of Arizona: effects of grazing, fire, and tree control. U.S. Dep. Agr. Product Res. Rep. 84. 28 p.

Aro, R.S. 1971. Evaluation of pinyon-juniper conversion to grass. J. Range Manage. 24:188-197.

Bouyoucos, G.J. 1962. Hydrometer method improved for making particle size analysis of soils. Agron. J. 54:464-465.

Branson, F.A., G.F. Gifford, and J.R. Owens. 1972. Rangeland hydrology. Soc. Range Manage. Denver, Colo., Range Sci. Ser. I. 84 p

Dortignac, E.J. 1951. Design and operation of Rocky Mountain infiltrometer. U.S. Dep. Agr., Forest Service, Rocky Mountain Forest Range Exp. Sta., Fort Collins, Colo. Sta. Pap. 5. 68 p.

Dortignac, E.J. 1960. Water yield from pinyon-juniper woodland. p. 1627 In: Water Yieldin Relation to Environment in the Southwestern United States. Amer. Ass. Advance Sci. Symp., Sul Ross State Coll., Alpine, Texas. May 3. 74 p.

Duncan, D.B. 1955. Multiple range and multiple $F$ tests. Biometrics 11:142.

Gifford, G.F. 1978. Use of infiltration equation coefficients as an aid in defining hydrologic impacts of range management schemes. J. Range Manage. 31:115-117

Gifford, G.F. 1979. Infiltration dynamics under various rangeland treatments on uniform sandy-loam soils in southeastern Utah. J. Hydrol. 42:179-185

Gifford, G.F., R.H. Faust, and G.B. Coltharp. 1977. Measuring soil compaction on rangelands. J. Range Manage. 30:457-460.

Gifford, G.F., and R.H. Hawkins. 1978. Hydrologic impact of grazing on infiltration ranges - a critical review. Water Resour. Res. 14:305-313.

Hoover, M.D., D.F. Olson, Jr., and L.J. Metz. 1954. Soil sa mpling for pore space and percolation. U.S. Dep. Agr., Forest Service, Southeast Forest Exp. Sta., Asheville, North Carolina. Sta. Pap. 42.29 p.

Ibrahim, K.M. 1971. Ocular point quadrat method. J. Range Manage. 24:312.

Jaynes, R.A., and G.F. Gifford. 1980. An in-depth examination of the Philip equation for cataloging infiltration characteristics in rangeland environments. J. Range Manage. (in print).

Kincaid, D.R., J.L. Gartner, and H.A. Schreiber. 1964. Soil and vegetation parameters affecting infiltration under semi-arid conditions. Internat. Ass. Sci. Hydrol., Pub. 65. p. 440-453.

Lull, H.W. 1959. Soil compaction on forest and range lands. U.S. Dep. Agr. Misc. Pub. 768. 33 p.

Marston, R.B. 1952. Ground cover requirements for summer storm runoff control on aspen sites in northern Utah. J. Forest 50:303-307.

Meeuwig, R.O. 1970. Infiltration and erosion as influenced by vegetation and soil in northern Utah. J. Range Manage. 23:185-188.

Meeuwig, R.O., and P.E. Packer. 1976. Erosion and runoff on forest and rangelands. p. 105-116. In: Proc. Watershed Management on Range and Forest Lands. Utah State Univ., Water Res. Lab., Logan. June 15-22, 1975. $222 \mathrm{p}$.

Packer, P.E. 1951. An approach to watershed protection criteria. J. Forest 49:639-644.

Pearse, C.K., and S.B. Woolley. 1936. The influence of range plant cover on the rate of absorption of surface water by soil. J. Forest. 34:844-847.

Rauzi, F., C.L. Fly, and E.J. Dyksterhuis. 1968. Water intake on midcontinental rangelands as influenced by soil and plant cover. U.S. Dep. Agr. Tech. Bull. 1390. 58 p.

Rauzi, F., and A.R. Kuhlman. 1961. Water intake as affected by soil and vegetation on certain western South Dakota rangelands. J. Range manage. 14:267-271

Rauzi, F., and D.E. Smika. 1963. Water intake on rangeland as affected by simulated grazing and fertilization. J. Range Manage. 16:125-128.

Rauzi, F., and F.M. Smith. 1973. Infiltration rates: three soils with three grazing levels in northeastern Colorado. J. Range Manage. 26:126-129.

Reynolds, H.G., and P.E. Packer. 1962. Effects of trampling on soil and vegetation. p. 116-112 In: Range Research Methods: A Symposium. Denver, Colorado. U.S. Dep. Agr. Misc. Pub. 940.172 p.

Thompson, J.R. 1968. Effect of grazing on infiltration in a western watershed. J. Soil Water Conserv. 23:63-65.

Wolff, D.N. 1970. Grassland infiltration phenomena. Natural Res. Ecol. Lab., Colorado State Univ., Fort Collins. Grassland Biome Tech. Rep. 54. $125 \mathrm{p}$. 